\title{
A role of zinc in the regulation of gene expression
}

\author{
Robert J. Cousins \\ Food Science and Human Nutrition Department, University of Florida, 201 FSHN, Gainesville, FL 32611-0370, USA
}

Nutritional regulation of gene expression is recognized as an important, albeit relatively new, area of research in nutrition. There are two major routes for nutrients to influence the extent to which a specific gene is expressed. The first is the scenario in which the nutrient has a direct interaction with cellular constituents, usually transcription factors, altering the rate of transcription and the cellular abundance of a given mRNA. Retinoids, calcitriol and certain sterols and fatty acids act as ligands that bind to specific transcription factors and alter a gene or a family of genes in this way. $\mathrm{Zn}$ is able to alter expression by a comparable mechanism in which metal occupancy in a site on a transcription factor is necessary to increase the rate of transcription. Fe influences the abundance of specific mRNA by binding to proteins which interact with mRNA to enhance or repress their translation. The second route for nutrients to alter expression is through any of a number of indirect interactions where secondary mediators respond to the nutrient's dietary supply. Various signal transduction systems and hormonal or cytokine stimuli may be involved. These areas of gene regulation by nutrients have been reviewed (Cousins, 1998).

\section{Functions of zinc in gene expression}

The focus of the present review is on $\mathrm{Zn}$ and how its abundance in the diet influences gene expression. Examples will be presented which potentially demonstrate both previously mentioned routes for gene regulation by this micronutrient. There is extensive literature which describes the effects of $\mathrm{Zn}$ on growth (Mills, 1989). Consequently, $\mathrm{Zn}$ has been viewed for decades as a factor in protein synthesis required for growth and development. $\mathrm{Zn}$ has functions that can be characterized in three general areas: catalytic, structural and regulatory (Cousins, 1995, 1996). Each function can be related in some way to gene expression.

RNA synthesis is an essential component of gene expression and $\mathrm{Zn}^{2+}$ ions are required for catalytic activity of the RNA polymerases (RNA nucleotide transferases which are $\mathrm{Zn}$ metallo-enzymes). Early literature is filled with examples of how $\mathrm{Zn}$ restriction decreases aspects of gene activity (for review, see Prasad \& Oberleas, 1976). Experiments with Euglena showed how a lack of $\mathrm{Zn}$ correlated with cessation of growth, which could be reestablished with $\mathrm{Zn}$ repletion. This was believed to be a reflection of the limited availability of $\mathrm{Zn}$ for the protein synthetic mechanisms and DNA replication (Falchuk \& Vallee, 1985). Similarly, experimental animals show suspended growth when their diet is severely restricted in $\mathrm{Zn}$ content (Mills, 1989). The resulting lack of growth could be caused by a lack of $\mathrm{Zn}$ required for gene expression. However, the cessation of growth is more likely to be a secondary response to a stimulus (stimuli) to restrict the energy-requiring processes needed for additional cell replication and protein synthesis.

The structural role for $\mathrm{Zn}$ is best demonstrated in the zinc-finger motif of proteins (Klug \& Schwabe, 1995; Schwabe \& Fairall, 1995). Evidence suggests that $1 \%$ of the genome codes for zinc-finger proteins. There is general agreement that the tetrahedral coordination of the $\mathrm{Zn}^{2+}$ involves four cysteine and/or histidine residues in various arrangements (four cysteine; two cysteine, two histidine; three cysteine, one histidine), and that the stability constants are relatively high (on the order of $10^{12} \mathrm{M}$ ). However, there is some evidence that $\mathrm{Zn}^{2+}$ in the finger with three cysteine residues and one histidine residue exists at low occupancy or is easily exchanged in vivo (Hempe \& Cousins, 1991; Kosa et al. 1994). While the majority of the zinc-finger proteins are transcription factors, others may participate in protein-protein interactions that provide signalling via kinase-binding domains. There has been little investigation of the effect of dietary $\mathrm{Zn}$ status on zincfinger proteins, and how regulation of specific genes could be affected. As antibodies become available to study such potential changes, data should soon become available to answer these questions. Since ubiquitous transcription factors, such as $\mathrm{Sp}-1$, have functional zinc-finger domains, if $\mathrm{Zn}$ depletion reduces function it would have major consequences on gene expression and growth.

The third function of $\mathrm{Zn}$ is regulatory and one that relates directly to gene expression. Also in this category is the involvement of $\mathrm{Zn}$ in synaptic signalling (Palmiter et al. 1996). That emerging area will not be discussed in the present focused review. The elucidation of the mode of regulation of the metallothionein gene is the only clear example to emerge where $\mathrm{Zn}^{2+}$ is able to directly regulate the transcription rate of a gene (Cousins, 1994). This is

Abbreviations: MRE, metal response elements; MTF, MRE-binding transcription factor; PCR, polymerase chain reaction Corresponding author: R. J. Cousins, fax +1 352392 1008, email cousins@gnv.ifas.ufl.edu 
accomplished through the interaction of a $\mathrm{Zn}^{2+}$-binding transcription factor that recognizes specific sequences (metal response elements; MRE) in the metallothionein promoter. $\mathrm{Zn}^{2+}$ binding probably occurs in the cytosol, with translocation to the nucleus for DNA binding. There is some evidence that the core MRE sequence is present in the promoters of other genes (for review, see Cousins, 1994, 1995). Presumably, these will be regulated also by the dietary $\mathrm{Zn}$ supply. A scheme showing the various ways in which $\mathrm{Zn}$ could influence gene expression is shown in Fig. 1.

The remainder of the present review will discuss the involvement of dietary $\mathrm{Zn}$ in the nuclear $\mathrm{Zn}$ pool, dietary regulation of the metallothionein gene, and use of differential mRNA display as an approach to identify genes that are regulated directly or indirectly by dietary $\mathrm{Zn}$.

\section{Nuclear zinc}

Fractionation studies have shown that about $25 \%$ of the $\mathrm{Zn}$ content of rat liver is found in the nuclear fraction (Smeyers-Verbeke et al. 1977). A significant amount of ${ }^{65} \mathrm{Zn}$ has been shown to be incorporated into nuclei in vitro (Weser \& Bischoff, 1970). We approached the transcriptional regulation of genes by $\mathrm{Zn}$ from the perspective that $\mathrm{Zn}^{2+}$ from the diet would participate in ligand binding to facilitate the activation of MRE-regulated genes. The consensus sequence for the MRE of the metallothionein promoter is CTCTGCRCNCGGCCC (Cousins, 1994), and was deduced in the laboratories of D. Hamer (Bethesda, MD, USA) and R. Palmiter (Seattle, WA, USA). The core sequence is underlined and $\mathrm{R}$ and $\mathrm{N}$ represent the purine base' and 'any base' respectively. The development of the MRE concept has been reviewed previously (Cousins, 1994).

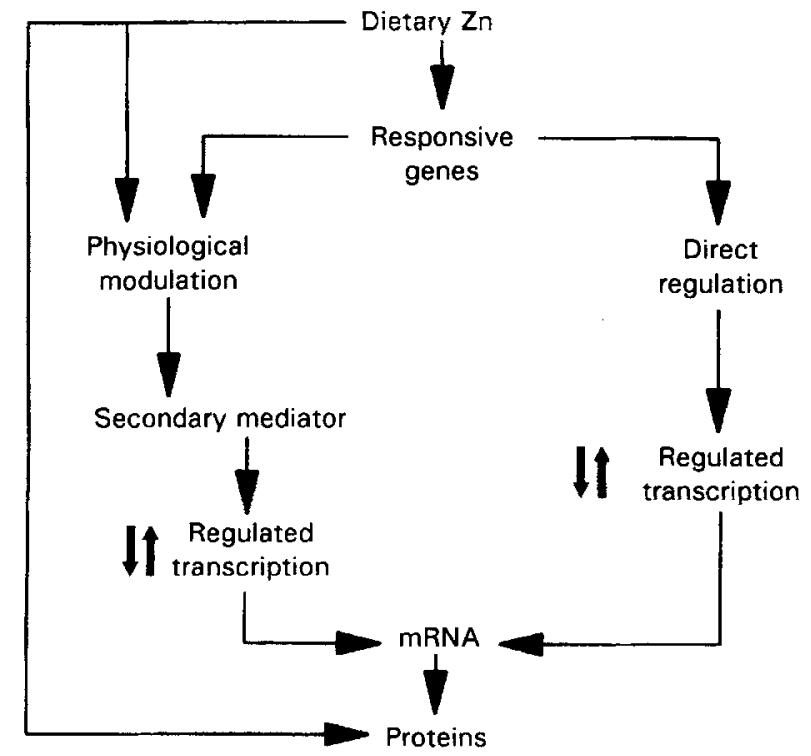

Fig. 1. A schematic representation of the ways in which zinc could influence gene expression.
The abundance of an MRE-binding transcription factor (MTF) would be expected to be very low relative to other transcription factors, which tend to be low-abundance proteins (Cousins, 1994). Attempts to isolate MTF from tissue extracts have not met with generally satisfactory results. Using molecular cloning techniques, an MTF (MTF-1) has been identified in human and animal cells (for review, see Dalton et al. 1997). MTF-1 may be constitutively produced, and active when an inhibitor is absent. An inhibitor molecule has not been identified. An alternative model suggests that MTF- 1 binds $\mathrm{Zn}^{2+}$ as a lower affinity site than other zinc-finger transcription factors (Radtke et al. 1993). Recently, a zinc-finger domain of MTF-1 has been suggested as the site of $\mathrm{Zn}^{2+}$ occupancy required for a positive mode of regulation for MRE genes. Dietary regulation of MTF-1 has not been examined.

We approached the question of MRE regulation from a nutrition perspective to (a) quantify the amount of nuclear $\mathrm{Zn}$ arising from the diet (using ${ }^{65} \mathrm{Zn}$ ), and (b) see if that dietary $\mathrm{Zn}$ could be identified with a specific nuclear protein(s) isolated by traditional protein-isolation methods (Cousins \& Lee-Ambrose, 1992). Growing rats were given purified diets based on the AIN-76A formulation (Blalock et al. 1988) containing 5, 30, $180 \mathrm{mg} \mathrm{Zn} / \mathrm{kg}$ diet. This produced the expected differential in metallothionein expression (both 1 and 2 rodent isoforms) in highlyexpressing tissues, i.e. liver, kidney and intestine. Subsequently, nuclei were purified from liver, kidney and spleen using a discontinuous-sucrose-gradient method. Except for the spleen where the low $\mathrm{Zn}$ intake increased nuclear $\mathrm{Zn}$, the nuclear $\mathrm{Zn}$ content of these tissues ( $\mathrm{pmol} \mathrm{Zn} / \mu \mathrm{g}$ DNA as measured by atomic absorption spectrometry) was not significantly influenced.

To examine the interaction between nuclear $\mathrm{Zn}$ and dietary $\mathrm{Zn}$, rats were dosed with a liquefied form of the same diets to which ${ }^{65} \mathrm{Zn}$ was added as an extrinsic label. At $2 \mathrm{~h}$ after the dose, nuclei were purified from liver, kidney and spleen using the same discontinuous-gradient method. After correcting for specific activity and DNA content, the incorporation of dietary $\mathrm{Zn}$, as indicated by ${ }^{65} \mathrm{Zn}$, was expressed as pmol $\mathrm{Zn} / \mu \mathrm{g}$ DNA. Liver nuclei had the greatest amount of ${ }^{65} \mathrm{Zn}$ from the diet. In each tissue, the value was proportional to the $\mathrm{Zn}$ content of the diet. In the case of the kidney, as much as $6 \%$ of $\mathrm{Zn}$ in the nuclei appears to have been derived from the diet in the $2 \mathrm{~h}$ experimental period. This suggested that there is considerable exchange of nuclear $\mathrm{Zn}$ with cellular $\mathrm{Zn}$ obtained from the dietary supply.

Using Sephacryl S-200 column chromatography, nuclear proteins extracted by a traditional approach (Cousins \& Lee-Ambrose, 1992) yielded two ${ }^{65} \mathrm{Zn}$ peaks. A clearlydefined DNA-binding protein labelled with ${ }^{65} \mathrm{Zn}$ was identified by further purification with heparin sepharose chromatography. Western and Southwestern blotting of these fractions showed evidence of a nuclear protein that bound both ${ }^{109} \mathrm{Cd}$ and ${ }^{65} \mathrm{Zn}$, and a ${ }^{32} \mathrm{P}$-labelled multimer of the MRE sequence. Collectively, these findings suggest that the mode of action of dietary $\mathrm{Zn}$ in the regulation of MRE genes is via direct interaction with a MTF molecule that, on metal occupancy and entry into the nucleus, initiates transcription. 


\section{Zinc and expression of human metallothionein}

For over a decade, we have been interested in the response of human metallothionein as a model system to gain information about $\mathrm{Zn}$ status in human subjects. The approach is aimed at developing a 'functional' assessment of $\mathrm{Zn}$ status. We reasoned that the direct correlation between dietary $\mathrm{Zn}$ intake and metallothionein expression seen in rats (Blalock et al. 1988; Cousins \& Lee-Ambrose, 1992) should be applicable to man.

Our initial approach was to develop an ELISA for human metallothionein (Grider et al. 1989, 1990). The successful use of a radioimmunoassay for rat metallothionein by Bremner and coworkers (Sato et al. 1984; Robertson et al. 1989) suggested that metallothionein protein levels in plasma and erythrocytes are responsive to dietary $\mathrm{Zn}$ intake. Our ELISA was used to define the general kinetics of metallothionein induction in erythrocyte-progenitor cells and the release of metallothionein-enriched reticulocytes into the circulation (Grider et al. 1990). Approximately $5 \mathrm{~d}$ after adult human subjects start to consume a daily $\mathrm{Zn}$ supplement $(50 \mathrm{mg} / \mathrm{d})$, the erythrocyte metallothionein concentration increases many fold. The level remains elevated until $\mathrm{Zn}$ supplementation has ceased. More recently, an ELISA based on the sandwich approach has yielded similar results, with comparable kinetics and level of induction (Sullivan \& Cousins, 1998). Studies with rats show that $\mathrm{Zn}$-induced metallothionein synthesis is observed in the reticulocyte precursor cells of the bone marrow, most probably through a Zn-dependent process involving MREMTF interaction (Huber \& Cousins, 1993a,b). Metallothionein induction in these cells is also responsive to anaemia and acute blood loss (Robertson et al. 1989; Huber \& Cousins, 1993b).

These studies with human subjects establish that metallothionein synthesis responds to dietary $\mathrm{Zn}$ intake and, as such, may provide a method to measure $\mathrm{Zn}$ status under controlled conditions. Furthermore, erythrocyte metallothionein synthesis may serve as a method to assess $\mathrm{Zn}$ bioavailability based on a function of $\mathrm{Zn}$, i.e. MRE regulation of a gene.

Since erythrocyte metallothionein is subject to certain physiological stimuli, we also investigated regulated synthesis in a leucocyte population. Monocytes had been identified as the cells with the highest level of expression (Pauwels et al. 1994). After verifying the latter, we found that metallothionein mRNA levels by Northern blot analysis and metallothionein protein levels by ELISA were too low for evaluation with the amount of monocytes obtained with a reasonable blood sample $(10 \mathrm{ml})$. To circumvent this problem, we developed a competitive reverse transcriptase-polymerase chain reaction (PCR) method to measure metallothionein mRNA via its conversion to cDNA. The latter is quantified using a cDNA of known concentration that is simultaneously amplified by PCR using the same primers. Details of the method have been reported recently (Sullivan \& Cousins, 1997).

In subjects receiving a $\mathrm{Zn}$ supplement of $50 \mathrm{mg} / \mathrm{d}$, monocyte metallothionein mRNA levels were elevated after only $1 \mathrm{~d}$ of supplementation (Sullivan \& Cousins, 1998). As with erythrocyte metallothionein protein, the
mRNA levels in monocytes remained elevated for the duration of supplementation. They returned to the basal levels within $4 \mathrm{~d}$ of supplementation. These results reflect the rapid turnover of monocytes. The mRNA levels do not correlate with plasma $\mathrm{Zn}$ concentration, suggesting induction occurs while the progenitor cells are in the bone marrow rather than after these cells are released into the peripheral circulation. Again, the response of monocyte metallothionein mRNA may provide a useful approach to measure $\mathrm{Zn}$ bioavailability using an established function, and be useful in defining a physiological function for this protein (and $\mathrm{Zn}$ ) in man.

\section{Identification of zinc-responsive genes by differential mRNA display}

The basic mechanisms responsible for the clinical signs and pathology of $\mathrm{Zn}$ deficiency continue to be an enigma. Attempts to relate these to decreased activities of various metallo-enzymes have not delineated the biochemistry involved (Mills, 1989). Our approach to answer this question is to examine which genes are under-expressed or over-expressed in nutritional $\mathrm{Zn}$ deficiency. As described in the introduction to the present brief overview and shown in Fig. 1, $\mathrm{Zn}$ can influence gene expression either via the MRE-MTF or similar complexes to directly alter transcription rates or by a secondary mediator that is responsive to $\mathrm{Zn}$ nutritional status. We have used differential screening and, more recently, differential mRNA display to identify genes influenced in some way by $\mathrm{Zn}$ deficiency, since that information may provide a clue as to which genes are affected.

Our initial studies used a differential screening method (Shay \& Cousins, 1993). A cDNA library was constructed from intestinal mRNA of $\mathrm{Zn}$-deficient rats ( $<1 \mathrm{mg} \mathrm{Zn} / \mathrm{kg}$ ). This was screened using ${ }^{32}$ P-labelled cDNA probes generated from intestinal mRNA of both $\mathrm{Zn}$-deficient and $\mathrm{Zn-adequate}$ rats. This technique can accommodate only one pair of dietary comparisons. A number of cDNA, (proportional in abundance to the parent mRNA) were decreased in abundance in $\mathrm{Zn}$ deficiency. These included apolipoprotein-A1, cytochrome-b, ubiquitin, cryptdin, cytochrome-c oxidase ( $E C$ 1.9.3.1) and fatty acid-binding protein. In contrast, a number of cDNA were increased in Zn deficiency.

While the differential screening technique demonstrated that mRNA differentially expressed by changes in the dietary Zn supply could be identified, we changed emphasis after those initial studies to capitalize on a more-powerful, newly-developed technology, differential mRNA display. This technique was developed to identify differentiallyexpressed genes in cancer cells (Liang \& Pardee, 1992). This approach allows the comparison of three or more dietary treatment groups, i.e. $\mathrm{Zn}$ deficient $(<1 \mathrm{mg} \mathrm{Zn} / \mathrm{kg}$ ), $\mathrm{Zn}$ adequate ad libitum ( $30 \mathrm{mg} \mathrm{Zn} / \mathrm{kg}$ ) and $\mathrm{Zn}$ adequate but pair fed to the intake of the Zn-deficient group.

The technique of differential display uses reverse transcription to quantitatively convert mRNA into cDNA. The latter are simultaneously amplified by PCR. Two sets of PCR primers are used. The first is a $3^{\prime}$ primer that is an 
oligo $\mathrm{d}(\mathrm{T})$ primer with two non-T bases at the $3^{\prime}$ end. This is called the 'anchored primer' since it helps anchor cDNA synthesis at the end of the poly A tail and $3^{\prime}$ untranslated region of the mRNA during reverse transcription. A set of four such anchored primers is needed for each of the four nucleotides. A $5^{\prime}$ primer is used along with the $3^{\prime}$ primer for cDNA amplification by PCR. Labelling of the cDNA bands is with ${ }^{35} \mathrm{~S}$-dATP. An array of twenty-four decanucleotide $5^{\prime}$ primers (termed arbitrary primers) are used individually for the PCR reactions. Using the twenty-four antibody primers and four anchored primers require ninety-six separate reactions to cover the spectrum of possible cDNA that represent actively-transcribed genes within the genome. As with any method, the technique has limitations; for example, the length of the cDNA product generated. If the cDNA is very short, it may not provide information in the coding region essential for sequence identification. Once each reaction has been completed, the ${ }^{35}$ S-labelled cDNA are separated on polyacrylamide gels. Differentiallyexpressed bands are excised, subcloned to increase their abundance, and sequenced. The sequence information is then analysed by searching GenBank (National Center for Biotechnology Research, Bethesda, MD, USA) or other source, to identify the genes that are differentially regulated.

We initially tested this system with kidney mRNA, since we reasoned that metallothionein gene expression is decreased in $\mathrm{Zn}$ deficiency, and that differential expression should be detectable using differential display. A 208 base pair cDNA fragment was generated, having the sequence of rat metallothionein-1, and was found at markedly depressed levels in the $\mathrm{Zn}$-deficient rats, which also exhibited depressed weight gain and serum $\mathrm{Zn}$ concentrations.

Intestinal mRNA has been the principal focus in our initial studies. Some mRNA increased while others were found to decrease in the $\mathrm{Zn}$-deficient rats. Occasionally, the mRNA in the pair-fed and ad libitum control groups differed. These were not considered further since those differences are likely to be related to differences in food intake. Two differentially-expressed genes are of particular interest, since both relate to the pathophysiology of $\mathrm{Zn}$ deficiency; both are over-expressed in $\mathrm{Zn}$ deficiency. The first is the gene for cholecystokinin, a peptide hormone that has endocrine and neurocrine effects on pancreatic secretion and satiety respectively (Blanchard \& Cousins, 1996). It is, therefore, of particular interest that the compromised pancreatic function and anorexia of $\mathrm{Zn}$ deficiency (Mills, 1989) would appear to correlate with up-regulation of the cholecystokinin gene. The second over-expressed gene is for the precursor of the peptide hormone uroguanylin. The uroguanylin hormone is produced in enterochromaffin cells of the intestine, and acts in a paracrine fashion to activate the production of cGMP, which stimulates the cystic fibrosis transmembrane conductance regulator and leads to increased fluid secretion into the intestine (Blanchard \& Cousins, 1997). This finding is in agreement with those of intervention studies in which $\mathrm{Zn}$ supplementation decreased the incidence of secretory diarrhoea in children (Sazawal et al. 1995; Rosado et al. 1997).
The findings made thus far, showing that cholecystokinin and uroguanylin gene expression are over-expressed, suggest that both could be used to explain aspects of the $\mathrm{Zn}$ deficiency syndrome. Further research using this and related technologies will certainly provide a clearer view of this nutrient deficiency, particularly as it is now being applied to genes expressed in other tissues, such as the thymus.

\section{Summary}

$\mathrm{Zn}$, without question, has important functions related to gene expression. Newer technologies applied to address these functions are providing answers relating to the importance of this micronutrient in human and animal health.

\section{References}

Blalock TL, Dunn MA \& Cousins RJ (1988) Metallothionein gene expression in rats: Tissue-specific regulation by dietary copper and zinc. Journal of Nutrition 118, 222-228.

Blanchard RK \& Cousins RJ (1996) Differential display of intestinal mRNAs regulated by dietary zinc. Proceedings of the National Academy of Sciences USA 93, 6863-6868.

Blanchard RK \& Cousins RJ (1997) Upregulation of rat intestinal uroguanylin mRNA by dietary zinc restriction. American Journal of Physiology 272, G972-G978.

Cousins RJ (1994) Metal elements and gene expression. Annual Review of Nutrition 14, 449-469.

Cousins RJ (1995). Trace element micronutrients. In Molecular Biology and Biotechnology, pp. 898-901 [RA Meyers, editor]. New York: VCH Publishers.

Cousins RJ (1996) In Present Knowledge in Nutrition, 7th ed., pp. 293-306 [LJ Filer and EE Ziegler, editors]. Washington, DC: International Life Sciences Institute-Nutrition Foundation.

Cousins RJ (1998) Nutritional regulation of gene expression. In Modern Nutrition in Health and Disease, 9th ed. [ME Shils, JA Olson, $\mathrm{M}$ Shike and $\mathrm{AC}$ Ross, editors]. Baltimore, MD: Williams \& Wilkins (In the Press).

Cousins RJ \& Lee-Ambrose LM (1992) Nuclear zinc uptake and interactions and metallothionein gene expression are influenced by dietary zinc in rats. Journal of Nutrition 122, 56-64

Dalton TP, Bittel D \& Andrews GK (1997) Reversible activation of mouse metal response element-binding transcription factor 1 DNA binding involves zinc interaction with the zinc finger domain. Molecular and Cellular Biology 17, 2781-2789.

Falchuk KH \& Vallee BL (1985) Zinc and chromatin structure, composition and function. In Trace Elements in Man and Animals - TEMA 5, pp. 48-55 [CF Mills, I Bremner and JK Chester, editors]. Slough: Commonwealth Agricultural Bureaux.

Grider A, Bailey LB \& Cousins RJ (1990) Erythrocyte metallothionein as an index of zinc status in humans. Proceedings of the National Academy of Sciences USA 87, 1259-1262.

Grider A, Kao KJ, Klein PA \& Cousins RJ (1989) Enzyme-linked immunosorbent assay for human metallothionein: Correlation of induction with infection. Journal of Laboratory and Clinical Medicine 113, 221-228.

Hempe, JM \& Cousins RJ (1991) Cysteine-rich intestinal protein binds zinc during transmucosal zinc transport. Proceedings of the National Academy of Sciences USA 88, 9671-9674. 
Huber KL \& Cousins RJ (1993a) Metallothionein expression in rat bone marrow is dependent on dietary zinc but not dependent on interleukin-1 or interleukin-6. Journal of Nutrition 123, 642648.

Huber KL \& Cousins RJ (1993b) Zinc metabolism and metallothionein expression in bone marrow during erythropoiesis. American Journal of Physiology 264, E770-E775.

Klug A \& Schwabe JWR (1995) Zinc fingers. FASEB Journal 9, 597-604.

Kosa JL, Michelsen JW, Louis HA, Olsen JI, Davis DR, Beckerle MC \& Winge DR (1994) Common metal ion coordination in LIM domain proteins. Biochemistry 33, 468-477.

Liang P \& Pardee AB (1992) Differential display of eukaryotic messenger RNA by means of the polymerase chain reaction. Science 257, 967-971.

Mills CF (1989) Zinc in Human Biology. New York: SpringerVerlag.

Palmiter RD, Cole TB, Quaife CJ \& Findley SD (1996) ZnT-3, a putative transporter of zinc into synaptic vesicles. Proceedings of the National Academy of Sciences USA 93, 1493414939.

Pauwels M, Van Weyenbergh J, Soumillion A, Proost P \& De Ley M (1994) Induction by zinc of specific metallothionein isoforms in human monocytes. European Journal of Biochemistry 220, $105-110$.

Prasad AS \& Oberleas D (1976) Trace Elements in Human Health and Disease. vol. 1, Zinc and Copper. New York: Academic Press Inc.

Radtke F, Heuchel R, Georgiev O, Hergersberg M, Gariglio M, Dembic Z \& Schaffner W (1993) Cloned transcription factor MTF-1 activates the mouse metallothionein I promoter. EMBO Journal 12, 1355-1362.
Robertson A, Morrison JM, Wood AM \& Bremner I (1989) Effects of iron deficiency on metallothionein-I concentrations in blood and tissues of rats. Journal of Nutrition 119, 439-445.

Rosado JL, López P, Munoz E, Martinez H \& Allen LH (1997) Zinc supplementation reduced morbidity, but neither zinc nor iron supplementation affected growth or body composition of Mexican preschoolers. American Journal of Clinical Nutrition 65, 13-19.

Sato M, Mehra RK \& Bremner I (1984) Measurement of plasma metallothionein-1 in the assessment of the zinc status of zincdeficient and stressed rats. Journal of Nutrition 114, 1683.

Sazawal S, Black RE, Bhan MK, Bhandari N, Sinha A \& Jalla S (1995) Zinc supplementation in young children with acute diarrhea in India. New England Journal of Medicine 333, 839844.

Schwabe JWR \& Fairall L (1995) Zinc finger DNA binding motifs. In Molecular Biology and Biotechnology, pp. 979-984 [RA Meyers, editor]. New York: VCH Publishers.

Shay NF \& Cousins RJ (1993) Cloning of rat intestinal mRNAs affected by zinc deficiency. Joumal of Nutrition 123, 35-41.

Smeyers-Verbeke J, May C, Drochmans P \& Massart DL (1977) The determination of $\mathrm{Cu}, \mathrm{Zn}$, and $\mathrm{Mn}$ in subcellular rat liver fractions. Analytical Biochemistry 83, 746-753.

Sullivan VK \& Cousins RJ (1997) Competitive reverse transcriptase-polymerase chain reaction shows that dietary zinc supplementation in humans increases monocyte metallothionein mRNA levels. Journal of Nutrition 127, 694-698.

Sullivan VK \& Cousins RJ (1998) Methallothionein expression is increased in monocytes and erythrocytes of young men during zinc supplementation. Journal of Nutrition (In the Press).

Weser U \& Bischoff $E$ (1970) Incorporation of ${ }^{65} \mathrm{Zn}$ in rat liver nuclei. European Journal of Biochemistry 12, 571-575. 